\title{
Treatment of Tannery Wastewater with Nano-Electrocoagulation Process
}

\author{
Abubaker Tajelsir Osman ${ }^{1 *}$, Mohamed Rahmtalla Elamin² and Mohammed Hassan Almalki ${ }^{3}$ \\ ${ }^{1}$ Industrial Research and Consultancy Center, IRCC, Sudan \\ ${ }^{2}$ Al Imam Mohammad Ibn Saud Islamic University (IMSIU) and IRCC, Sudan \\ ${ }^{3}$ Advanced Materials and Nano Research, Najran University, Najran, KSA
}

\begin{abstract}
This work, aims to treat tannery wastewater sample to remove or reduce the pollutants load by using electrocoagulaion technique using an electrode of aluminum nanoparticles. The aluminum nanoparticles were synthesized using sol-gel method and characterized with XRD, TEM, SEM, EDX and FTIR. All the results show that these materials were in nano range. XRD pattern showed that the diameter of aluminum particles was around $14 \mathrm{~nm}$ and a peak at 2 theta 18 of aluminum hydroxide. TEM and SEM images of aluminum nanoparticles confirmed the XRD results. The EDX and FTIR indicate the presence of oxygen and hydroxyl ions accompanying the preparation of aluminum nanoparticles. The investigation of the tannery waste water showed high signs of pollution. The $\mathrm{pH}$, turbidity, COD, TDS, chromium, sulphide, chloride and sulphate were 7, 13900 NTU, 10155 ppm, 462 ppm, 28950 ppm, 412 ppm, 6471.5 ppm and $5995 \mathrm{ppm}$ respectively. All these values exceed the limits of the industrial effluent standards, except for the $\mathrm{PH}$. In electrocoagulation treatment at $80 \mathrm{~mA}, 3 \mathrm{~h}$ and $\mathrm{pH}$ 7, succeeded to remove best $98.98 \%, 90.6 \%, 70.40 \%, 99.9 \%$ and $88.3 \%$ of Turbidity, COD, TDS, Chromium and Sulphide respectively.
\end{abstract}

Keywords: Electrocoagulation; Tannery waste water; Aluminum nanoparticles electrode; Turbidity; Chromium

\section{Introduction}

The water consumption and effluent disposal in the leather industry is considered as a serious environmental threat. About $85 \%$ of fresh water used in leather processing, is disposed off as wastewater, carrying dissolved and suspended chemicals and other substances used in the process, creating serious pollution problems [1]. There are four operating processes applied to leather until it becomes a final product, these are; pretanning operation (Beam House Operation), tanning operation, wet- finishing operation and finishing operation. Every tanning step, with exception of the crust finishing operations, produces wastewater. An average of $35 \mathrm{~m}^{3}$ of wastewater is produced per ton of raw hide [2].

This wastewater contains: salts $(\mathrm{NaCl})$, fat, protein, preservatives from soaking; lime, ammonium salts, ammonia, protein (hair), and sulphides from fleshing, trimming, bating steps; chromium (salts) and poly phenolic compounds from tanning; and dye and solvent chemicals from wet-finishing step. Toxic effects of tannery waste were caused by the presence of toxic chemicals such as sulphides, chromates and other tanning agents that may interfere biological waste treatment. Toxic discharges retard the process of selfpurification and sometimes may cause the death of aquatic life [3]. It is important to determine the principal impurities in the effluent and to pretreat these impurities as necessary step before being released to the sewer, river or lakes. Many industrial effluent contaminants can be eliminated by mechanical, biological or chemical methods [410] nanotechnology has been extensively studied by researchers as it offers potential advantages like low cost, reuse and high efficiency in removing and recovering the pollutants of industrail wastewater $[11,12]$.

Electrochemical preparation methods are one of the possible and powerful options for the fabrication of a new class of nanomaterials. It is useful to develop methods which are less expensive and lead to similar quality of final products. Electrocoagulation (EC) is a process that does not require the addition of anyexternal coagulants; the coagulationflocculation process is very similar to chemical coagulation, except that the coagulant is generated in-situ through the dissolution of sacrificial anodes that are connected to an electric current [13].

The process involves connecting metal electrodes to a direct current generator. The chosen metal should be suitable for use as sacrificial anodes; that is, it should produce metal cations in the solution. Aluminum and iron are the materials of choice because they produce a higher valence. Hydroxyl ions and hydrogen gas formed at the cathode, and metal ions are released at the anode by electrolytic oxidation of the metal electrode [14]. The main objectives of this work are to: prepare and characterize aluminum nanoparticles and use them as anode in an electrocoagulation cell to treatment tanneries waste water.

\section{Experimental Work}

$10 \mathrm{mmol}$ of aluminum carbonate(AR) and $30 \mathrm{mmol}$ of lithium aluminum hydride(AR) were added to $110 \mathrm{ml}$ of dipropylene glycol(AR). The mixture was refluxed at $140^{\circ} \mathrm{C}$ for 90 minutes and stirred with magnetic stirrer on a hot plate. The nitrogen gas was inserted to isolate the solution from the oxidation. The product was collected by centrifugation at $16000 \mathrm{rpm}$ for $15 \mathrm{~min}$. The solution was decanted and the product was washed with anhydrous ethanol several times, filtered and dried in an oven at $105^{\circ} \mathrm{C}$ for 2 hours [15]. Characterization of aluminum phases nanoparticles was carried using XRD, (XRD; PANalytical X'Pert PRO) and Scanning Electron Microscopy (FESEM; JEOL-JSM- 7600F) and Transmission Electron Microscopy (TEM; JEOL-JEM-2100) and in Figures 1-3 explains the pattern and the images of aluminum phases.

*Corresponding author: Abubaker Tajelsir Osman, Industrial Research and Consultancy Center, IRCC, Sudan, Tel: +966175428888; E-mail: bakry114@gmail.com

Received September 05, 2017; Accepted September 23, 2017; Published September 29, 2017

Citation: Osman AT, Elamin MR, Almalki MH (2017) Treatment of Tannery Wastewater with Nano-Electrocoagulation Process. J Environ Anal Toxicol 7: 508. doi: 10.4172/2161-0525.1000508

Copyright: @ 2017 Osman AT, et al. This is an open-access article distributed under the terms of the Creative Commons Attribution License, which permits unrestricted use, distribution, and reproduction in any medium, provided the original author and source are credited. 
Citation: Osman AT, Elamin MR, Almalki MH (2017) Treatment of Tannery Wastewater with Nano-Electrocoagulation Process. J Environ Anal Toxicol 7: 508. doi: 10.4172/2161-0525.1000508

Page 2 of 7

A composite sample of the tannery wastewater was collected in a plastic container from the White Nile tannery, Sudan. The sample was analyzed for Chemical Oxygen Demand (COD), $\mathrm{pH}$, chromium content, turbidity, Total Dissolved Solid (TDS) and sulphide before and after the treatment according to Standard Methods for the Examination of Water and Wastewater (SMWW4000 - 6000) [16] and compared with the Sudanese wastewater treatment standards [17]. Electrocoagulation treatment trials were conducted in $600 \mathrm{ml}$ glass beakers. During the treatment, waste water was stirred with magnetic stirrer.

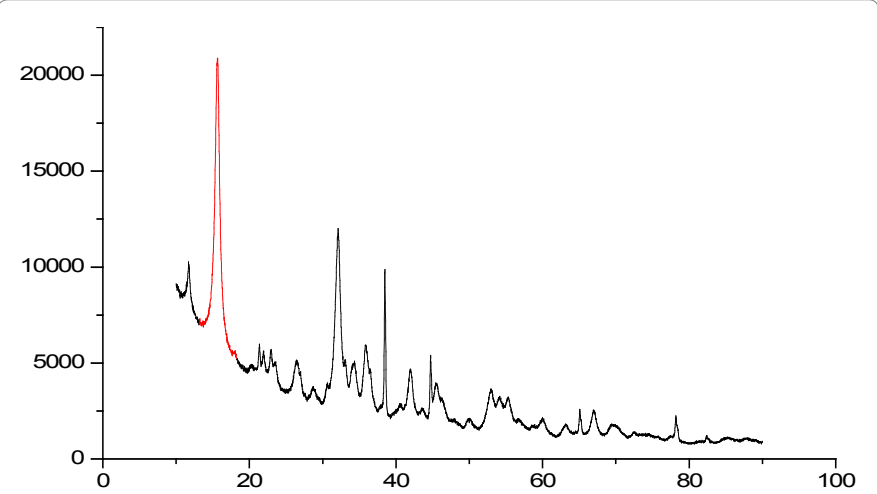

Figure 1: XRD pattern of aluminum phases nanoparticles.
The Aluminum nanopowder was pressed in the compressor using 5 ton in a mold and tested until it gave solid mould and good conductivity for electric current. A copper wire was inserted in the pressed aluminum powder electrode. The aluminum electrode dimensions are $50 \mathrm{~mm}, 30 \mathrm{~mm}, 3 \mathrm{~mm}$. The anode was a carbon column obtained from a dry battery for the electrochemical cell. The distance between the electrode plates was $40 \mathrm{~mm}$. Standard laboratory power supplies were used in the experiments. $300 \mathrm{ml}$ of wastewater samples at certain $\mathrm{pH}$ values were poured into the reactor. The samples were filtered on 0.45 micron filter paper and analyzed for different parameters. The efficiency of treatment at electrical potentials of 20,40,60 and $80 \mathrm{~mA}$ and different $\mathrm{pH}$ values of 3,7 and 10, and time intervals of 1,2 and 3 hours were determined.

\section{Results and Discussion}

The particle size of the of aluminum nanoparticles was characterized by X-ray diffraction (XRD; PAN alyticalX'Pert PRO) using Sherrer's equation $\mathrm{D}=\mathrm{k} \lambda / \beta \cos \varphi$ and found to be $14 \mathrm{~nm}$. When comparing the obtained spectrum with the standard patterns of aluminum phases [18], we can conclude to that, the intense peak at 2 theta 18 may be due to aluminum hydroxide phase $\mathrm{Al}(\mathrm{OH})_{3}[19]$. The other peaks represent the characteristic peaks of aluminum metal resulting as the pattern explained in Figure 1. SEM images of the aluminum nanoparticles exhibit cloudy cotton like morphology as in Figures 2a and 2b, showed particle size was $100 \mathrm{~nm}$.
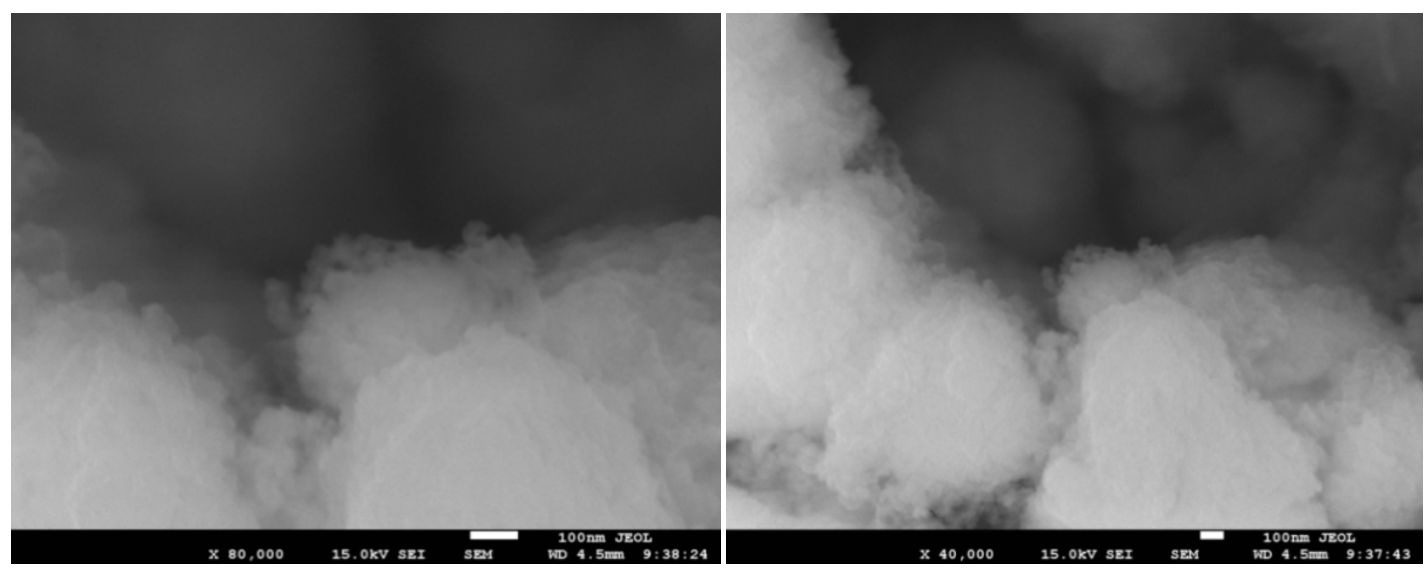

Figure 2: SEM image of aluminum nanoparticles.
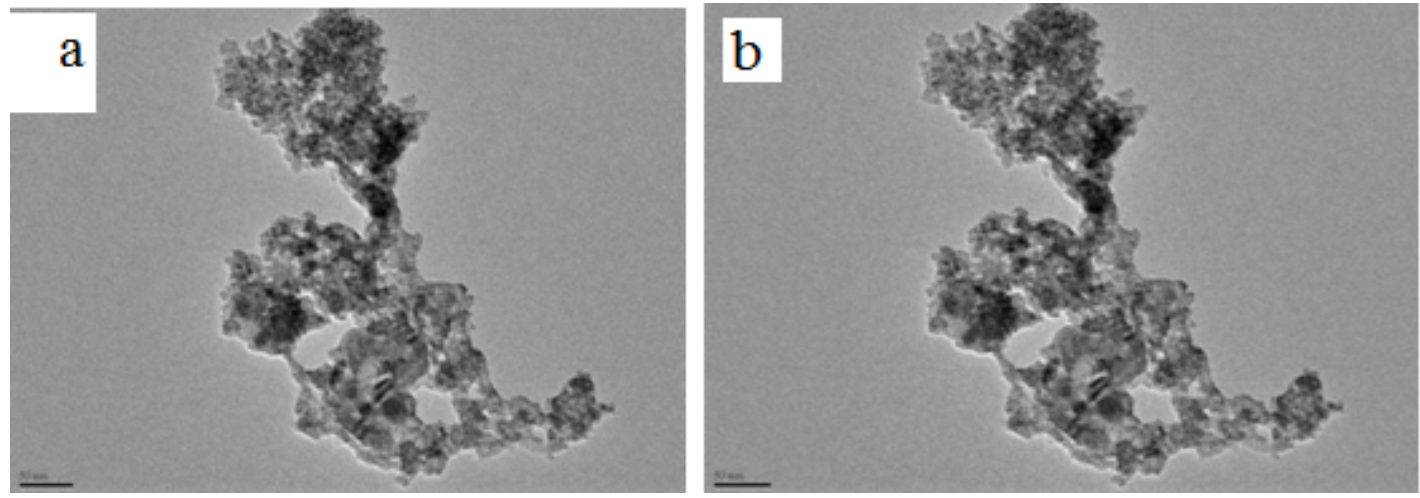

Figure 3: TEM image of the aluminum metal nanoparticles 
Citation: Osman AT, Elamin MR, Almalki MH (2017) Treatment of Tannery Wastewater with Nano-Electrocoagulation Process. J Environ Anal Toxicol 7: 508. doi: 10.4172/2161-0525.1000508

Page 3 of 7

TEM images confirmed the approximate particle size calculated from the XRD pattern, where Figures $3 a$ and $3 b$, showed particle size less than $20 \mathrm{~nm}$. The EDX chart of aluminum nanoparticles showed the presence of oxygen peak indicating the expected oxidation of outer surface aluminum nanoparticles when react with air oxygen, this confirmed the presence of aluminum oxide peaks in the XRD pattern.

The FTIR (FTIR; Perkin Elmer-FTIR Spectrum-10) spectrum of aluminum nanoparticles was shown in Figures 4 and 5 . The spectrum showed absorption peak in the range $1200-1300 \mathrm{~cm}^{-1}$, due to the bending mode of aluminum-oxygen bonds [20]. The broad and weak peak around $2750 \mathrm{~cm}^{-1}$ may indicate the hydroxyl absorption of the aluminum hydroxide appeared in the XRD pattern. The investigations of the tannery waste water showed highly polluted effluent. All the examined parameters, except $\mathrm{pH}$, exceed the Sudanese industrial discharge limits [15], as shown in Table 1.
When electrocoagulation treatment was applied to the tannery waste water at $\mathrm{pH} 3,7$ and 10 , at variable currents for different time periods, the pollutants decreased appreciably with variable proportions for all currents and in all time periods as shown below. Before treatment the turbidity value was found to be 13900 NTU which is higher than the Sudanese industrial wastewater limit (40 NTU). The Figures 6-8 blow illustrates the effect of $\mathrm{pH}$ on the removal of turbidity during the 1,2 and 3 hours of the contact time at current densities of $20,40,60,80 \mathrm{~mA} / \mathrm{cm}^{2}$. The best removal efficiency at $\mathrm{pH} 7$, was obtained at 3 hour contact time and $80 \mathrm{~mA}$, where $99.6 \%$ of the turbidity was removed. In $\mathrm{pH} 10$ at 3 hours reaction period and $80 \mathrm{~mA} / \mathrm{cm}^{2}$ current density the removal of suspended materials was $100 \%$. In $\mathrm{pH} 3$, in 3 hours reaction period at $80 \mathrm{~mA} / \mathrm{cm}^{2}$ current density the removal of suspended materials was also $100 \%$ [16-23].
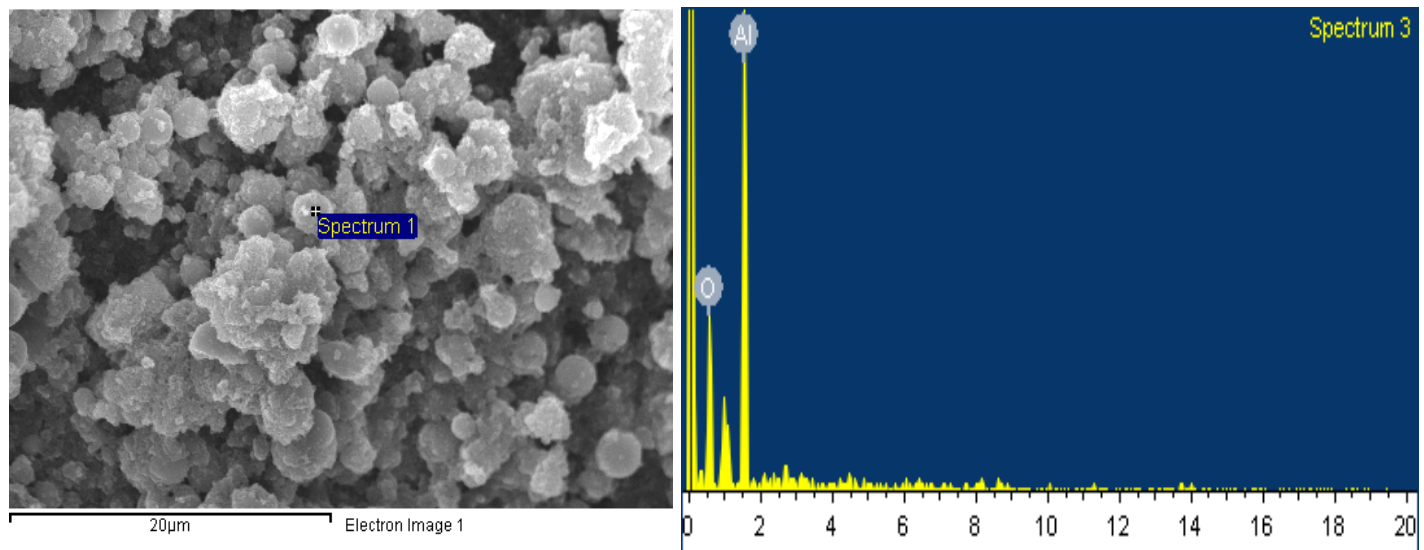

Figure 4: SEM-EDX image of aluminium metal nanoparticles.

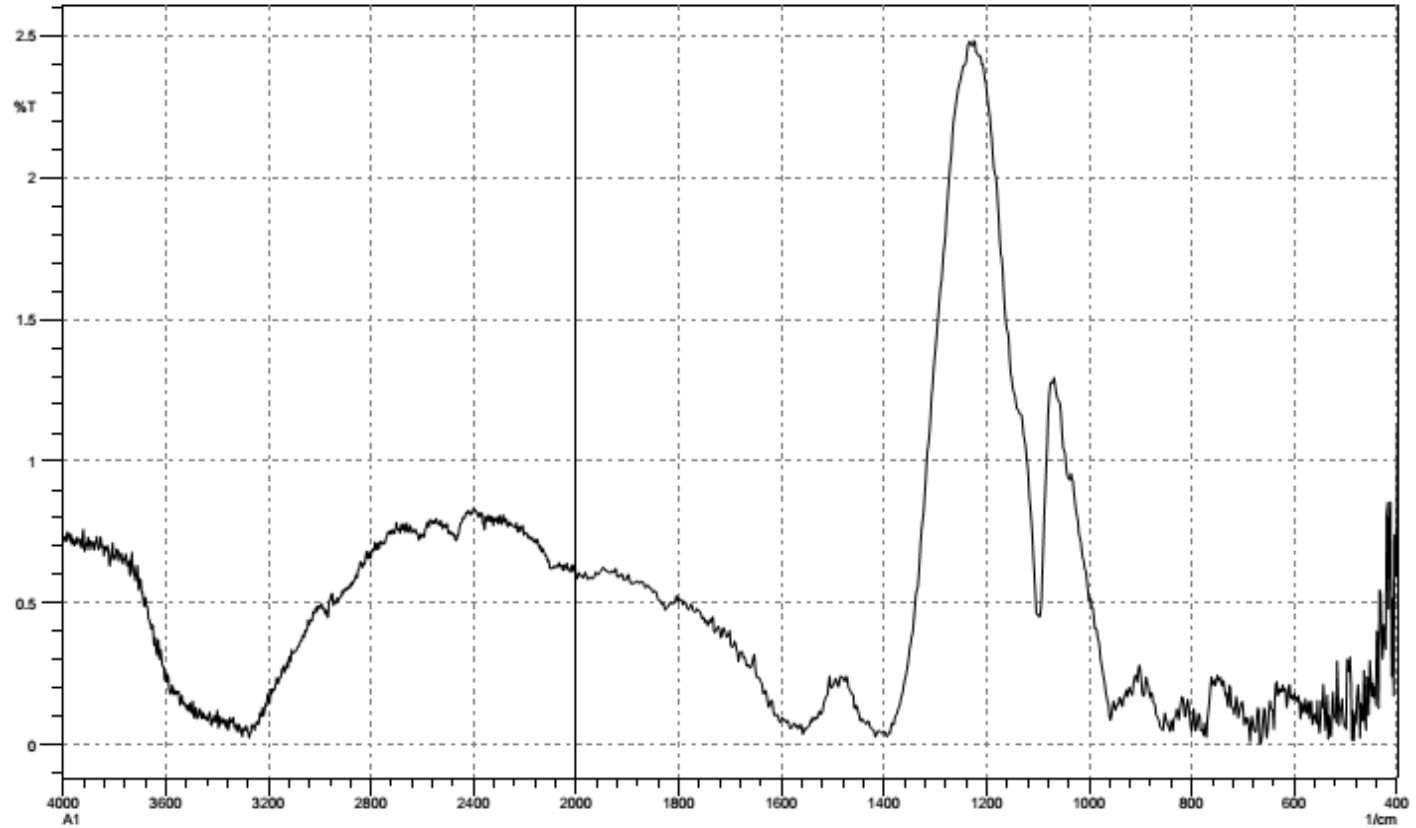

Figure 5: FTIR spectrum of aluminium nanoparticles. 
Citation: Osman AT, Elamin MR, Almalki MH (2017) Treatment of Tannery Wastewater with Nano-Electrocoagulation Process. J Environ Anal Toxicol 7: 508. doi: 10.4172/2161-0525.1000508

Page 4 of 7

\begin{tabular}{|c|c|c|c|}
\hline No & Parameters & Concentration & STD limit \\
\hline 1 & $\mathrm{pH}$ & 7 & $6-9$ \\
\hline 2 & Turbidity & $13900 \mathrm{NTU}$ & $40 \mathrm{NTU}$ \\
\hline 3 & COD & $10155 \mathrm{pp}$ & $1000 \mathrm{ppm}$ \\
\hline 4 & Chromium & $462 \mathrm{ppm}$ & $1.5 \mathrm{ppm}$ \\
\hline 5 & TDS & $28950 \mathrm{ppm}$ & $2500 \mathrm{ppm}$ \\
\hline 6 & Sulphide & $412 \mathrm{ppm}$ & $2 \mathrm{ppm}$ \\
\hline 7 & Sulphate & $5995 \mathrm{ppm}$ & $300 \mathrm{ppm}$ \\
\hline 8 & Chloride & $6471.5 \mathrm{ppm}$ & $1000 \mathrm{ppm}$ \\
\hline
\end{tabular}

Table 1: Initial characterization of the tannery waste water and standard limits [17]

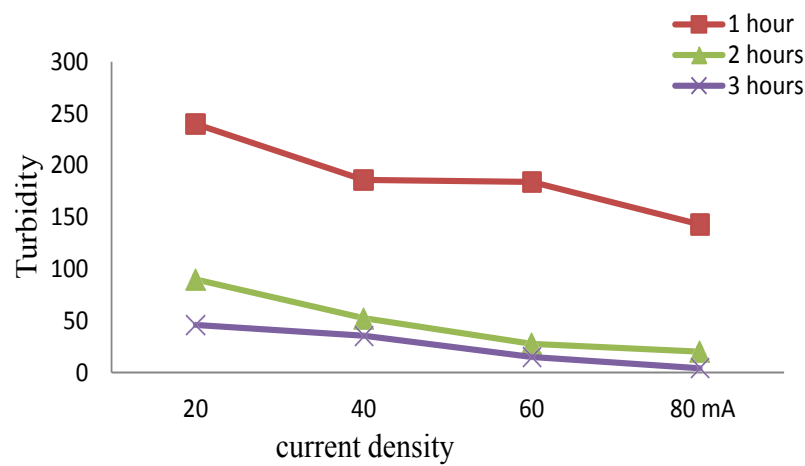

Figure 6: Turbidity values at different values of current and time at $\mathrm{pH} 7$.

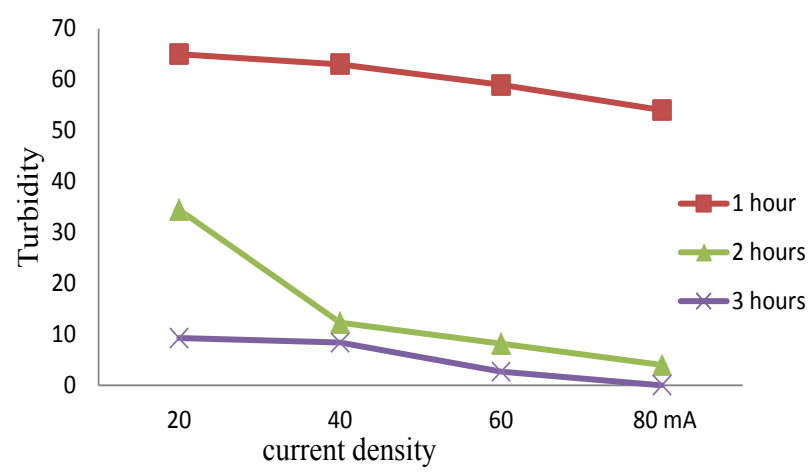

Figure 7: Turbidity values at different values of current and time at $\mathrm{pH} 10$.

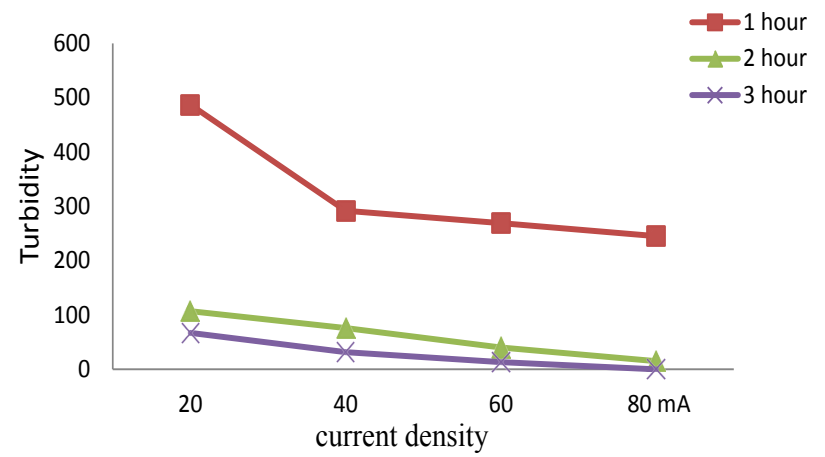

Figure 8: Turbidity values at different values of current and time at $\mathrm{pH} 3$.

The chemical oxygen demand, COD in tannery wastewater, was reduced to variable extents at the different parameters of the treatment, but it is still higher the allowed limits, except when the current density was $80 \mathrm{~mA}$ for 3 hours period where $955 \mathrm{ppm}$ value was obtained. Although, the COD was decreased by, 76.57 $5 \%, 90.60 \%$ and $79.84 \%$ at $\mathrm{PH} 3,7$ and 10 respectively at $80 \mathrm{~mA}$ and 3 hours period. Figures $9-11$ showed the trends. $28950 \mathrm{ppm}$ of Total dissolved solids (TDS), indicates the presence of high levels of soluble pollutants in the tannery wastewater, while the allowed limit is $2500 \mathrm{ppm}$. The best removal percentages, $70.40 \%$, was achieved at $\mathrm{pH} 7$, current density $80 \mathrm{~mA}$ and for 3 hours period. The highest removal percent of TDS was $66.2 \%$ and $64.5 \%$ at $\mathrm{pH} 10$ and 3 respectively at $80 \mathrm{~mA}$ current density and for 3 hours period. The chromium level was found to be $462 \mathrm{ppm}$ in TWW (Tables $1-6)$, this level exceeds the permissible chromium levels (1.5 ppm) of effluent discharged into inland surface waters. The best removal efficiency was $99.9 \%$ in 3 hours reaction period and $80 \mathrm{~mA}$ current density at $\mathrm{pH} 7$, also at 2 hours reaction period at 40,60 and the amount of chromium were in range of the permissible levels. At $\mathrm{pH} 10$ in 3 hour's reaction period the removal efficiency reached $99.8 \%$. At pH 3, removal, up to $87.3 \%$, was obtained at $80 \mathrm{~mA}$ and three hours contact time Figures 12-20. The sulfide, $S^{-2}$, content was found to be $412 \mathrm{ppm}$ in TWW, as a result of liming and unhairing process. $88.35 \%, 88.35 \%$ and $81.07 \%$ of the sulphide was removed at $\mathrm{PH} 3,7$ and 10 respectively at current density $80 \mathrm{~mA} / \mathrm{cm}^{2}$ and 3 hours contact time [24-29].

\begin{tabular}{|c|c|c|c|c|c|c|c|c|c|c|c|c|}
\hline \multirow{2}{*}{$\begin{array}{l}\text { TWW pH } \\
\text { Current mA } \\
\text { time }\end{array}$} & \multicolumn{4}{|c|}{$\mathrm{pH}=3$} & \multicolumn{4}{|c|}{$\mathrm{pH}=7$} & \multicolumn{4}{|c|}{$\mathrm{pH}=10$} \\
\hline & 20 & 40 & 60 & 80 & 20 & 40 & 60 & 80 & 20 & 40 & 60 & 80 \\
\hline 1 hour & 487 & 292 & 269 & 245 & 240 & 186 & 184 & 143 & 65 & 63 & 59 & 54 \\
\hline 2 hours & 107 & 76 & 40 & 15 & 90 & 52.6 & 27.7 & 20.2 & 34.5 & 12.3 & 8.2 & 4.0 \\
\hline 3 hours & 67 & 31.5 & 13.1 & 00 & 46 & 35.5 & 15.1 & 4.2 & 9.3 & 8.4 & 2.7 & 00 \\
\hline
\end{tabular}

Table 2: Turbidity in TWW at different $\mathrm{pH}$ values, currents density and reaction time.

\begin{tabular}{|c|c|c|c|c|c|c|c|c|c|c|c|c|}
\hline \multirow{2}{*}{$\begin{array}{c}\text { TWW pH } \\
\begin{array}{l}\text { Current mA/ } \\
\text { time }\end{array}\end{array}$} & \multicolumn{4}{|c|}{$\mathrm{pH}=3$} & \multicolumn{4}{|c|}{$\mathrm{pH}=7$} & \multicolumn{4}{|c|}{$\mathrm{pH}=10$} \\
\hline & 20 & 40 & 60 & 80 & 20 & 40 & 60 & 80 & 20 & 40 & 60 & 80 \\
\hline 1 hour & 6912 & 5804 & 4592 & 2944 & 5712 & 4680 & 3738 & 2500 & 6496 & 4680 & 3338 & 2640 \\
\hline 2 hours & 6178 & 4903 & 3865 & 2734 & 4490 & 3638 & 2433.6 & 1288 & 4299 & 3764 & 3038 & 2352 \\
\hline 3 hours & 5511 & 3744 & 3266 & 2380 & 3364 & 3061 & 2014 & 955 & 3677 & 3325 & 2856 & 2048 \\
\hline
\end{tabular}

Table 3: COD of TWW at different $\mathrm{pH}$ values, current density and reaction time. 
Citation: Osman AT, Elamin MR, Almalki MH (2017) Treatment of Tannery Wastewater with Nano-Electrocoagulation Process. J Environ Anal Toxicol 7: 508. doi: 10.4172/2161-0525.1000508

Page 5 of 7

\begin{tabular}{|c|c|c|c|c|c|c|c|c|c|c|c|c|}
\hline \multirow{2}{*}{$\begin{array}{l}\text { TWW pH } \\
\text { Current mA/ } \\
\text { time }\end{array}$} & \multicolumn{5}{|c|}{$\mathrm{pH}=3$} & \multicolumn{3}{|c|}{$\mathrm{pH}=7$} & \multicolumn{4}{|c|}{$\mathrm{pH}=10$} \\
\hline & 20 & 40 & 60 & 80 & 20 & 40 & 60 & 80 & 20 & 40 & 60 & 80 \\
\hline 1 hour & 23270 & 19355 & 16462 & 14105 & 24443 & 19050 & 16790 & 13920 & 22567 & 18900 & 14810 & 12965 \\
\hline 2 hours & 18900 & 16748 & 14870 & 12450 & 18835 & 16438 & 14299 & 10695 & 19902 & 16562 & 12768 & 10665 \\
\hline 3 hours & 15642 & 13864 & 11980 & 10282 & 16650 & 13960 & 11165 & 8570 & 16095 & 14897 & 11031 & 9790 \\
\hline
\end{tabular}

Table 4: TDS in TWW at different $\mathrm{pH}$ values, current density and reaction time.

\begin{tabular}{|c|c|c|c|c|c|c|c|c|c|c|c|c|}
\hline \multirow{2}{*}{$\begin{array}{l}\text { TWW pH } \\
\text { Current mA/ } \\
\text { time }\end{array}$} & \multicolumn{4}{|c|}{$\mathrm{pH}=3$} & \multicolumn{4}{|c|}{$\mathrm{pH}=7$} & \multicolumn{4}{|c|}{$\mathrm{pH}=10$} \\
\hline & 20 & 40 & 60 & 80 & 20 & 40 & 60 & 80 & 20 & 40 & 60 & 80 \\
\hline 1 hour & 112.9 & 109 & 106.4 & 104.6 & 3.456 & 2.218 & 1.863 & 1.676 & 2.280 & 2.004 & 1.811 & 1.406 \\
\hline 2 hours & 99.8 & 91.8 & 90.2 & 89.4 & 2.293 & 1.142 & 0.721 & 0.493 & 1.403 & 1.312 & 1.252 & 1.134 \\
\hline 3 hours & 87.7 & 81.3 & 67.2 & 58.6 & 1.223 & 0.896 & 0.614 & 0.416 & 1.331 & 1.307 & 1.143 & 0.509 \\
\hline
\end{tabular}

Table 5: Chromium in TWW at different pH values, current density and reaction time.

\begin{tabular}{|c|c|c|c|c|c|c|c|c|c|c|c|c|}
\hline \multirow{2}{*}{$\begin{array}{c}\text { TWW pH } \\
\text { Current mA/time }\end{array}$} & \multicolumn{4}{|c|}{$\mathrm{pH}=3$} & \multicolumn{4}{|c|}{$\mathrm{pH}=7$} & \multicolumn{4}{|c|}{$\mathrm{pH}=10$} \\
\hline & 20 & 40 & 60 & 80 & 20 & 40 & 60 & 80 & 20 & 40 & 60 & 80 \\
\hline 1 hour & 80 & 72 & 64 & 56 & 112 & 88 & 80 & 72 & 178 & 168 & 160 & 152 \\
\hline 2 hours & 64 & 56 & 56 & 56 & 94 & 72 & 64 & 56 & 164 & 160 & 152 & 114 \\
\hline 3 hours & 64 & 56 & 56 & 48 & 88 & 62 & 54 & 48 & 156 & 136 & 120 & 78 \\
\hline
\end{tabular}

Table 6: Sulphide in TWW at different $\mathrm{pH}$ values, current density and reaction time.

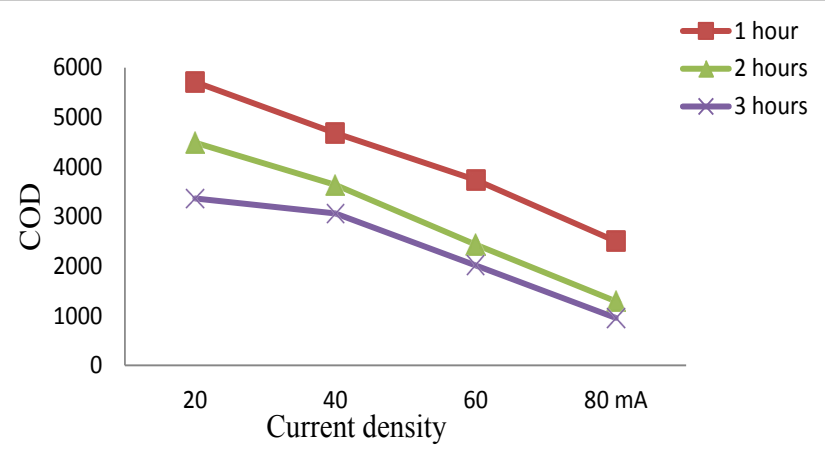

Figure 9: COD in different values of current and time at $\mathrm{pH} 7$.

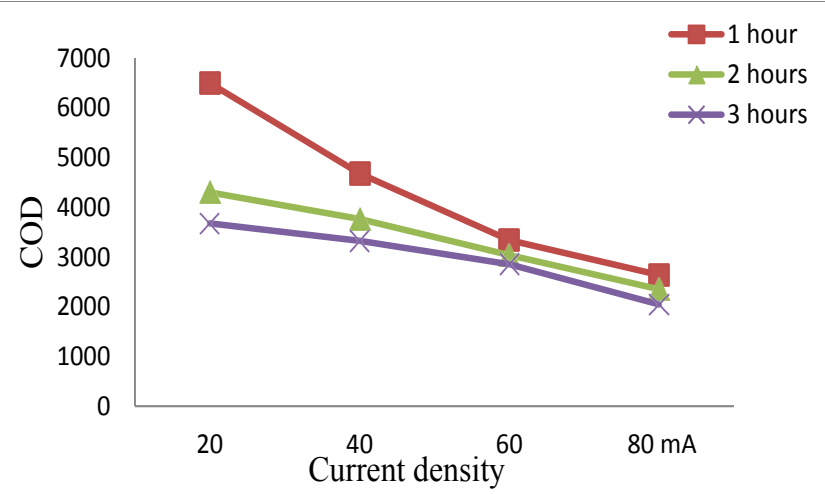

Figure 10: $\mathrm{COD}$ at different values of current and time at $\mathrm{pH} 10$.

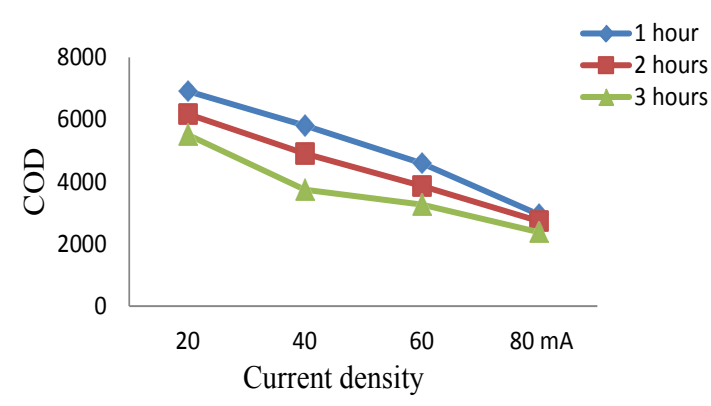

Figure 11: $\mathrm{COD}$ in different values of current and time at $\mathrm{pH} 3$.

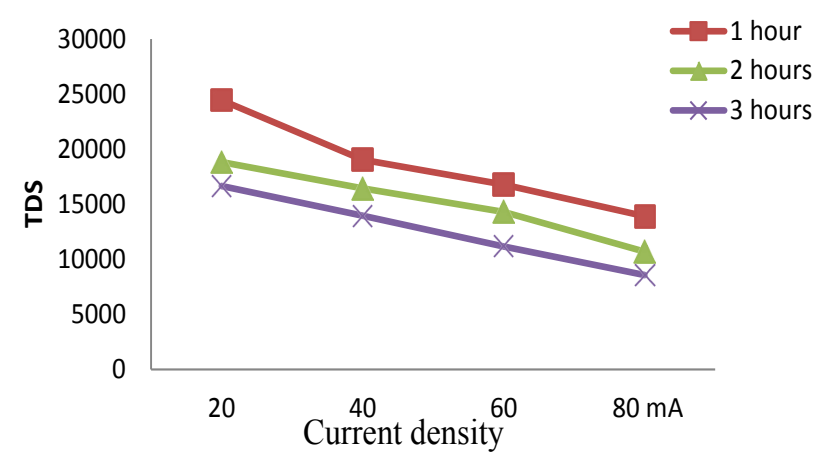

Figure 12: TDS values at $\mathrm{PH} 7$ and at different values of current and time. 
Citation: Osman AT, Elamin MR, Almalki MH (2017) Treatment of Tannery Wastewater with Nano-Electrocoagulation Process. J Environ Anal Toxicol 7: 508. doi: 10.4172/2161-0525.1000508

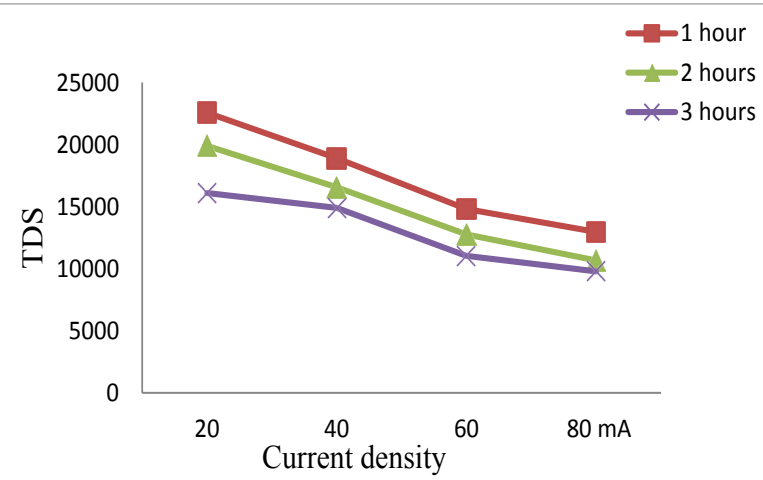

Figure 13: TDS content at different values of current and time at $\mathrm{pH} 10$.

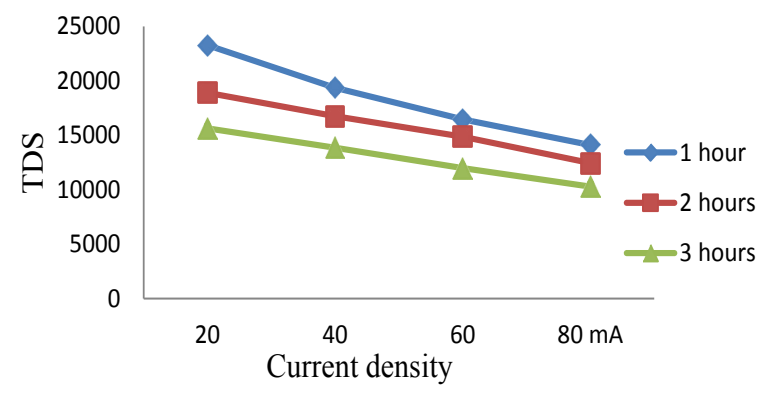

Figure 14: TDS at different values of current and time at $\mathrm{pH} 3$.

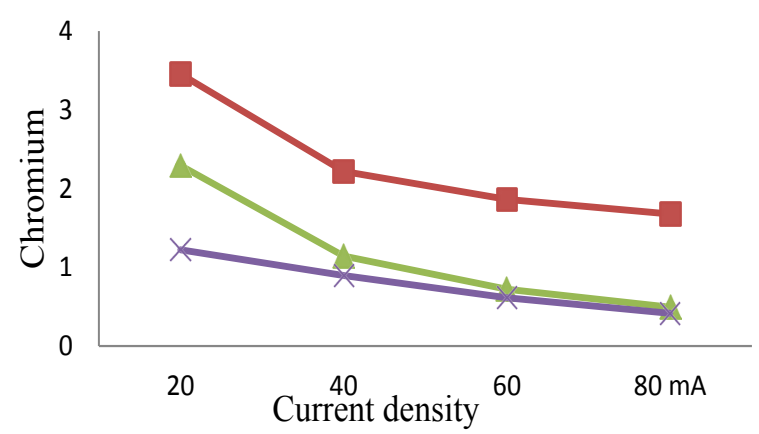

Figure 15: Chromium content at different values of current and time at $\mathrm{pH} 7$.

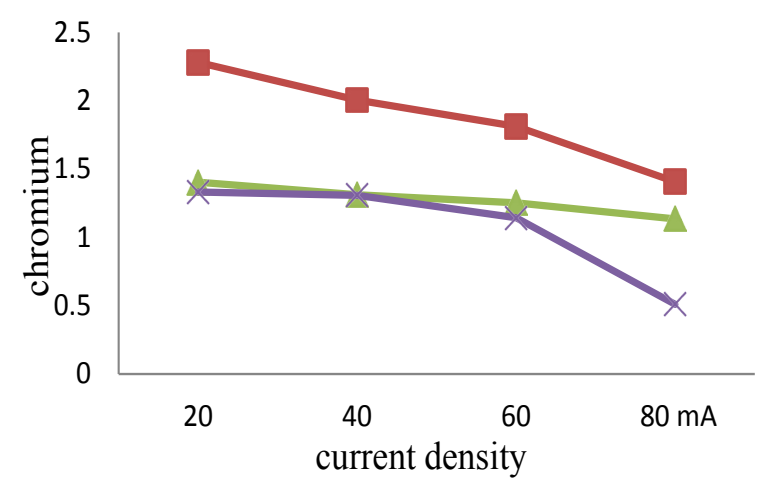

Figure 16: Chromium values at different values of current and time at pH 10 .

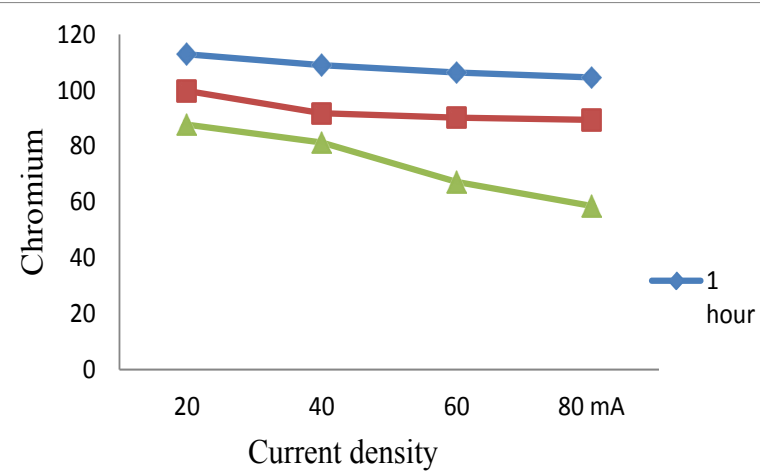

Figure 17: Chromium values at different values of current and time at $\mathrm{pH} 3$.

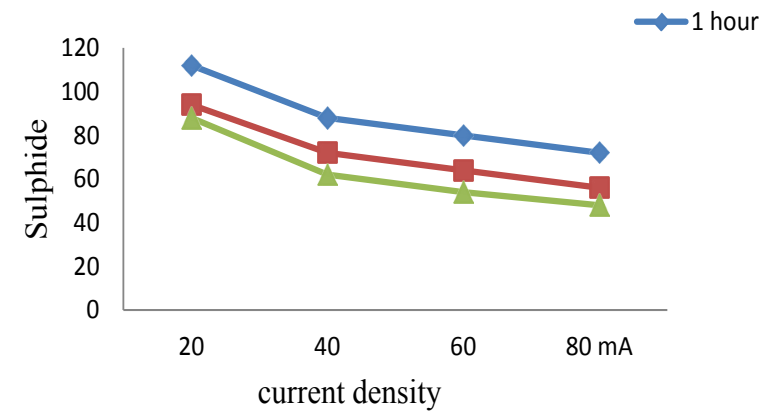

Figure 18: Sulphide values in different values of current and time at $\mathrm{pH} 7$.

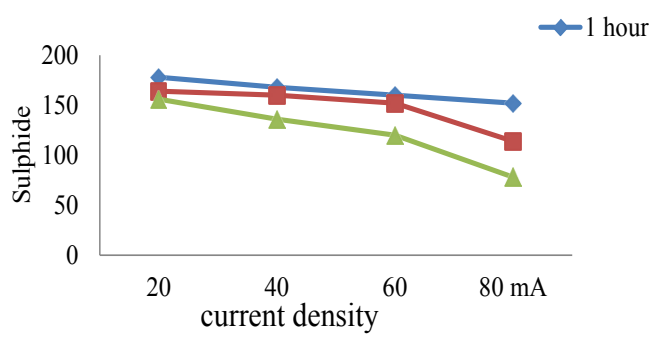

Figure 19: Sulphide values at different values of current and time at $\mathrm{pH} 10$.

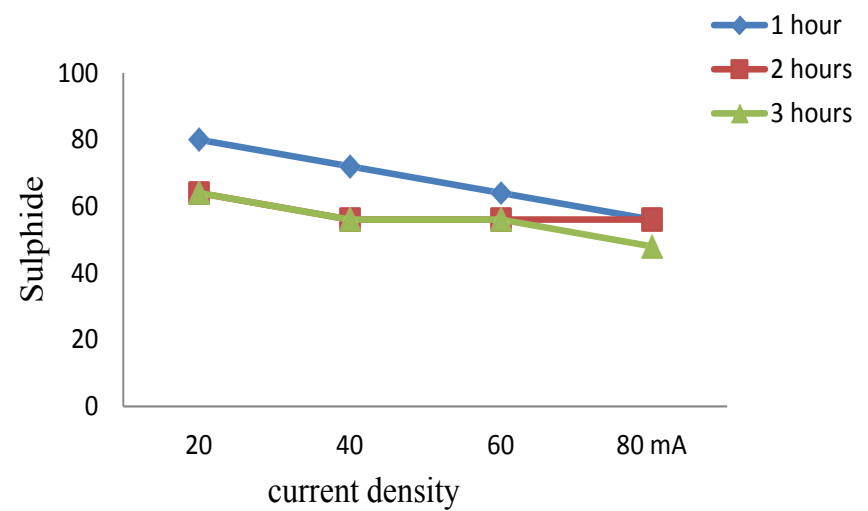

Figure 20: Sulphide values in different values of current and time at $\mathrm{pH} 3$. 
Citation: Osman AT, Elamin MR, Almalki MH (2017) Treatment of Tannery Wastewater with Nano-Electrocoagulation Process. J Environ Anal Toxicol 7: 508. doi: 10.4172/2161-0525.1000508

Page 7 of 7

\section{Conclusion}

The results of the analysis indicate that the White Nile tannery discharge is highly polluted liquid waste. In this study it was found that the electrocoagulation technique using aluminum nanoparticles electrode reduced turbidity, COD, sulphide and chromium to satisfactory levels. This technique could be used successfully as a pretreatment step for highly polluted tannery waste water.

\section{References}

1. United Nation Industrial Development Organization (UNIDO) (2015) Report: Waste generated in the leather products industry. Zlin, Czech Republic.

2. Karabay S (2008) Waste management in leather industry. Dokuz Eylul University, Turkey.

3. Bosnic M, Buljan J, Daniels RP (2000) Pollutants in tannery effluents definitions and environmental impact limits for discharge into water bodies and sewer. UNIDO; Regional Program for Pollution Control in the Tanning Industry in South-East Asia.

4. Hendrickx L, Boardman GD (1995) Pollution Prevention Studies in the Textile Wet Processing Industry. Study, Blacksburg, Virginia, New York, London.

5. Belay AA (2010) Impacts of Chromium from Tannery Effluent and Evaluation of Alternative Treatment Options. Journal of Environmental Protection 1: 53-58.

6. International Finance Corporation (IFC) (2007) Environmental, Health, and Safety Guidelines for Tanning and Leather Finishing, World Bank group.

7. Amuda OS, Alade A (2005) Coagulation and flocculation. 2nd edn. New York, USA.

8. Butler E, Hung YT, Yeh RY, Suleiman Al Ahmad M (2011) Electrocoagulation in Wastewater Treatment. J Water 3: 495-525.

9. Babu RR, Bhadrinarayana NS, Begum KM, Anantharaman N (2007) Treatment of tannery wastewater by electrocoagulation. Journal of the University of Chemical Technology and Metallurgy 2: 201-206.

10. El-Khalek MA (2011) Studies on industrial wastewater treatment by electrochemical coagulation. Ore Dressing 13: 26.

11. Qu X, Alvarez PJ, Li Q (2013) Applications of nanotechnology in water and wastewater treatment. Water Research 47: 3931-3946.

12. Tiwari DK, Behari J, Sen P (2008) Application of Nanoparticles in Waste Water Treatment. New Delhi, India, World Applied Sciences Journal 3: 417-433.

13. Bréchignac C, Houdy $P$, Lahmani M (2008) Nanomaterials and nanochemistry. Springer Science \& Business Media.

14. Kalska-Szostko B (2012) Electrochemical Methods in Nanomaterials
Preparation. In: Recent Trend in Electrochemical Science and Technology, University of Bialytsok, Poland.

15. Lee HM, Yun JY (2011) Preparation of Aluminum-Oleic Acid Nano-Composite for Application to Electrode for Si Solar Cells. Materials Transactions 52: 1222 1227.

16. APHA (2000) Standard Methods for the Examination of Water and Wastewater Including Bottom sediments and sludge. Published by American Public Health Association, American Water Works Association, Water Pollution Control Federation. 20th edn, USA.

17. SSMO 173/2008 (2008) Industrial Wastewater Treatment.

18. Swanson HE, Tatge E, Fuyat RK (1981) Standard X-ray Diffraction Powder Patterns. Washington, USA.

19. Goudarzi M, Ghanbari D, Salavati-Niasari M (2015) Room temperature preparation of aluminum hydroxide nanoparticles and flame retardant poly vinyl alcohol nanocomposite. Journal of Nanostructures 5: 110-115.

20. Devamani R, Alagar M (2012) Synthesis and characterization of aluminium phosphate nanoparticles. International Journal of Applied Science and Engineering Research 1: 769-775.

21. Sharma A, Anghore D, Awasthi R, Kosey S, Jindal S, et al. (2015) Nanotechnology: Synthesis, Structures and Properties 'a review of current carbon nanomaterials and other nanoparticle technologies and their applications in biomedicine. World Journal of Pharmacy and Pharmaceutical Science 4: 1088-1113.

22. Glen E, Guozhong F (2007) Environmental Applications of Nanomaterials Synthesis, Sorbents and Sensors. 2nd edn. London, England.

23. Edelstein AS, Cammarata RC (2001) Nanomaterials: Synthesis, Properties and Applications. UK.

24. Rao CN, Müller A, Cheetham AK (2006) The Chemistry of Nanomaterials Synthesis, Properties and Applications.

25. Mishra AK (2014) Application of Nanotechnology in Water Research. USA.

26. Ivie MA (2010) wet chemical synthesis strategies to develop aluminum manganese nanoparticles for high density magnetic recording. University of Alabama, USA.

27. Herrera JE, Sakulchaicharoen N (2016) Microscopic and Spectroscopic Characterization of Nanoparticles. Drug delivery nanoparticles formulation and characterization 191: 239.

28. Mirabet LP (2013) Synthesis, Characterization and Fuctionlization of metal and metal oxides nanoparticles. TEM microscopy study; Barcelona, Spain.

29. Akbari B, Tavandashti MP, Zandrahimi M (2011) Particle Size Characterization of Nanoparticles-A Practical approach. Iranian Journal of Materials Science and Engineering 15: 48-56. 